\title{
Weber and church governance: religious practice and economic activity
}

\section{Abstract}

The debate about the relationship between religion and economic activity in the wake of Weber has been cast largely in terms of belief and values. This article suggests an alternative focus on practice. It argues that taken for granted practices of church governance formed to-hand resources for the organization of economic activity. The argument is developed through an examination of the historical development of church governance practices in the Presbyterian Church of Scotland, with particular emphasis on the way in which theological belief gave rise to practices of accountability and record keeping. In turn such practices contributed to a 'culture of organization' which had implications for economic activity. A focus on governance practices can help to illuminate enduring patterns of difference in the organization of economic activity.

\section{Introduction}

With its stern rules and invigilation and penances the Kirk had evolved a type of Scot uniquely fitted to serve the empire as officer, or NCO, or policeman, overseer, manager; a Scot with an inbred instinct for harrying the unregenerate 
poor, or Negroes, or natives, for their own good as well as his employer's (Kiernan 1992: 98).

In their argument that the years since the 1960s have seen the creation of a 'new spirit of capitalism', Boltanski and Chiapello (2007) draw explicitly on Weber. Just the most recent authors to turn to his classic sociology of religion, their primary concern is with the idea that capitalism requires regimes of justification, what they idiosyncratically call 'cities', in order to function. Such 'cities' supply more or less coherent and patterned sets of ideas which provide not only justifications but motivations for engaging in economic activity. They note in passing Weber's original work on the connection between religious belief and the growth of capitalism, but this is not their main area of concern nor what they take substantively from Weber. The concern of this article is not with the validity or otherwise of the 'projective city' which they argue has been established through the works of the authors of management texts, but rather with a return to Weber. For arguments which invoke The Protestant Ethic and the Spirit of Capitalism (Weber 1976) pose a problem. As Campbell (2006) points out, while many cite this work as a classic, few replicate Weber's focus on individual psychology and motivation. Indeed, Hennis (1988) suggests that the very title of the work is misleading. Weber's focus on the relationship between personality and life orders would be better rendered, he argued, by replacing 'spirit of capitalism' with 'capitalist habitus'.

Informed by such insights, although leaving the detailed debate to one side, this article suggests that we approach Weber through a different lens, using that supplied by the new institutionalism in organizational analysis (DiMaggio 1998). A key 
element of this approach is its focus on taken-for-granted practices which condition action in other fields. Actors may not be consciously aware that they are transferring practices. Indeed, the most powerful resources are those which are seen as so 'natural' that they are obvious. I argue that at a crucial moment in the development of capitalism, taken-for-granted practices of church governance in the Presbyterian polity of Scotland contributed to a 'culture of organization' which laid the foundations for many modern practices of management, most notably in their translation to a different institutional environment, the United States of America.

The debate on Weber, religion and the rise of capitalism is an extensive and inconclusive one. What seems problematic is the link between forms of religious belief on the one hand and economic activity on the other. In a classic investigation of the experience of Presbyterianism in Scotland, the country with perhaps the most thoroughly realised instance of Calvinist Protestantism in Europe, Marshall (1980) found no convincing evidence of a link between religious belief on the one hand and business practice on the other. Much rested, of course, with problems of historical evidence, but in this article I want to suggest that there are hints in Marshall that point to an alternative approach that might be fruitful. This is a focus on taken-for-granted organizational practice. Marshall has an extensive discussion of the Newmills Cloth Manufactury, established in Haddingtonshire in the 1680s by a group of merchants:

There were at least four general meetings each year at which company policy was decided and accounts were examined, all decisions being arrived at on the basis of binding majority vote. At the meeting in May five members were elected as 'managers' and, after the first election, two remained in office and 
three new ones were elected each year. The managers met at least once a week, electing among themselves a 'praeses' (chairman) for each meeting. A quorum of three was necessary for business to proceed. The day to day running of the factory was, however, entirely in the hands of the 'Master', that is (in modern usage), 'paid manager' (Marshall, 1980: 145).

This organizational structure seems to borrow elements from church practice, especially the institution of the kirk session, suggesting that a further exploration of such elements is merited.

The argument, to be explored in more detail below, and the theoretical sources drawn upon to support it, runs as follows. The new institutionalism in organizational sociology draws our attention to the ways in which practices are transferred between fields (Scott 2001). This suggests a focus on the mundane, the quotidian and thetaken-for granted and that such practices often depend on those who cross boundaries and engage in processes of translation. Practices are often transferred effectively, that is, not because of some conscious process but because they are to-hand, legitimate and seen to be fit for the task in hand. More closely related to the study of religion, Wuthnow's (1989) magisterial survey of the Reformation suggests the need to explore how cultural products are brought into articulation with institutional contexts. Both of these approaches suggest a need to explore how religious practices are produced and become available to act as templates for use elsewhere. However, it is tempting to see such religious practices as in their turn as mere reflections of secular practice. So perhaps particular practices of church governance simply reflect existing mercantile practice or, more crudely, are functional responses to the need of commerce for 
factors such as trust (Stout and Cormode 1998). Such tendencies can be seen, in particular, in the literature generated by the economics of religion (Lechner 2007). By contrast, the approach taken here is one informed by Archer's injunctions about the primacy of practice and her emphasis that this applies to religious experience (Archer 2004). Hence, religious practices are seen as flowing initially from matters of belief. There is some small support for this in a rather underdeveloped observation of the Aston programme, which turned its lens fleetingly on matters of church organization (Ransom, Bryman and Hinings 1977). ${ }^{1}$ This is picked up to distinguish between liturgical practices, in particular Communion, where theological systems have a direct impact on organizational practices, and other aspects of church governance where the impact is a little more indirect.

After a more detailed exploration of these theoretical insights, they are applied to the case of Scotland to explicate them in a concrete setting. The way in which questions of organization lay at the heart of the Reformed Kirk's polity is outlined, with a particular focus on the organizational implications of Communion arrangements, Drawing largely on secondary sources, but with some limited evidence from archival research, this section explores how a 'culture of organization' evolved by the eighteenth century which subsequently provided a to-hand model for the development of management practice. The eminence of many Scots in the early development of management, both at home and in the Americas can be related to this culture of organization. Of course, it also has to seen in the context of an inter-related set of institutions, notably education and the law. This example is used to suggest that an alternative reading of Weber through a lens of organizational practice might be fruitful. The intention is not to provide a 'solution' to the debate over the Protestant 
ethic and the rise of capitalism, nor to seek to supplant that debate, but rather to suggest that an organizational focus leads us back to neglected parts of Weber and may help our understanding of patterns of difference.

\section{Religious belief and practices of church governance}

In his response to critics of The Protestant Ethic Weber insisted that

what interested me centrally was not what nurtured the expanding capitalism but the developing type of human being that was created out of the confluence of the religious and economic components (Chalcraft and Harrington 2001: 106).

Weber's interest in forms of church organization was therefore shaped above all by this concern with how they shaped personality types. He sketches in the impact of broad forms of organization, such as monasticism, but he has relatively little interest in exploring the detailed organizational practices so generated and any putative links between them and economic activity (Weber 1968b; Hennis 1988). There is much greater emphasis in the passages in Economy and Society on patterns of belief and comparisons between such beliefs in relation to a number of domains, including economic action (Weber 1968a). His work on organizational form, particularly, of course, on bureaucracy, is heavily influenced by his own experience of practices in Prussian government and army (Albrow 1994). While he notes the development of bureaucracy in the medieval Catholic church, he lays much more stress on the 
technical demands engendered by large scale government and commercial enterprise. He goes further to note that

The discipline of the army gives birth to all discipline. The large-scale economic organization is the second great agency which trains men for discipline (Gerth and Mills, 1948: 261).

However, this does tend to contradict some relatively little used passages in his work on religious sects. For Chalcraft (1994) this work is an essential complement to the Protestant Ethic. In it, Weber relates membership of sects to business success because of the certification of moral quality that membership tests provide. Two important facets here are the existence of membership and the denial of sacraments to any other than fully qualified members. So Weber notes that

The tremendous social significance of admission to full enjoyment of the rights of the sectarian congregation, especially the privilege of being admitted to the Lord's Supper, worked among the sects in the direction of breeding that ascetist professional ethic which was adequate to modern capitalism during the period of its origin (Gerth and Mills 1948: 312)

Weber goes on to note, although only in passing, some organizational concomitants of this restriction of sacraments, such as the circulation of certificates amongst congregations. This presupposed, as we will see later, further organizational practices such as the recording of membership. It also required specific roles to maintain 
discipline and the importance of lay elders is stressed. However, he continued even here to return to the central importance of the internalisation of ascetic values:

The church discipline of the Puritans and of the sects was vested, first, at least in part and often wholly, in the hands of laymen. Secondly, it worked through the necessity of one's having to hold one's own; and, thirdly, it bred or, if one wishes, selected qualities. The last point is the most important one (Gerth and Mills 1948: 316).

Hennis points out that for Weber 'in all social phenomena it is the non-everyday that interests him, that which bursts through everyday life' (Hennis 1988: 181). It is intriguing therefore that an approach such as the new institutionalism in organizational analysis, which takes as a key starting point ideas on bureaucracy perceived to emanate from Weber, takes just such a focus on the mundane as a central insight (DiMaggio and Powell 1991). It is not the purpose of this article to trace the intellectual roots of such a deviation from what Hennis would see as Weber's core concern but, for the purposes of this article, our focus will be precisely on such mundane practices and on the first part of Weber's observation, the involvement of lay members. This creation of a cadre of organizers together with the associated organizational practices laid the foundations, it will be argued, for a culture of organization and provided to-hand resources for other forms of organizing.

In order to pursue this point it will be necessary to elucidate the nature of the practices followed and their relation to belief. Much work in business and economic history places its stress on the functions that religion plays in an unregulated market 
economy, notably in supplying markers for trust. Thus the practices of groups like the Quakers and Baptists rested on the strength of internal discipline which guaranteed their financial probity to other members and often to non-believers (Prior and Kirby 1993; Garnett 1999). This enabled the institution of practices such as fixed pricing (Gerth and Mills 1948: 111; Weber 1968b). However, it is tempting to move to a functionalist form of argumentation, in which the needs of economic actors for trust call into being cultural responses. Such arguments lie at the root of much work in the economics of religion, profoundly influenced as it is by the work of rational choice theorists (Ekelund, Hebert and Tollison 2006). If we are to reject this impoverished view of human action then we need an approach which does not reduce all motivation to economic factors (Archer and Tritter 2000). This is Archer's (2004) argument when she challenges what she sees as the dominant secular atheism of social science. Her argument is that we learn from practice and that religious experience is worthy of being treated as an equally valid form of practice. One does not have to share her religious belief to grant the validity of this. What it suggests to us is that we take religious experience and hence belief seriously and recognize that belief conditions practice albeit in mediated form.

As Dyck and his collaborators have argued, 'surprisingly little of that research [on Weber] has specifically examined the relationship between the values evident in different religions and the practices of those religious organizations' (Dyck et al 2005: 52). If we look more broadly, to historical work which does not draw upon Weber, we can find examples, such as the local organizational forms of Mormonism (Arrington and Bitton 1979) or the governance practices of Ulster Presbyterians (Holmes A 2006), although such accounts are rare. In the context of the sociology of 
organizations, we can draw on an underdeveloped aspect of the Aston programme. Having argued for the impact of a number of factors on organization structure, several members of the project went on to consider whether their putative model could be applied to non-profit organizations. Of particular influence here is the work of Ranson, Bryman and Hinings (1977) on church organization. Their work explored the position of the clergy in three churches: the Church of England, the Roman Catholic church and the Methodist Church. Their conclusion was that denominational context and structures of theological belief were the most important factors in the shape of the organizational structure. This work focused on the role of the clergy and, whilst pointing to the involvement of the laity in passing, was little developed in other aspects. Its main focus in terms of organization, as with the later work of Jeremy (1988a), is with the degree of centralization or decentralization in organizational structure. This was seen to relate to theological beliefs, with the focus of Roman Catholicism on the importance of the church and priest in the transmission and maintenance of the faith being reflected in a hierarchical structure. However, these insights were little developed and promised future work never emerged. One problem with their sample is that whilst the three churches presented different examples of lay involvement, they are all churches with their origins in a form of church governance which stresses the importance of bishops and central control. As we will see, a broader examination gives us a different perspective on lay involvement in governance structures in particular. This perspective flows from a focus on taken-for-granted practice.

A practice based approach is of increasing importance in the study of contemporary organizations. For example, Whittington (2006) has argued for the need to explore strategy as practice. By this he means that other approaches tend to downplay the practices which are deployed to achieve the process of strategy making. The closer examination of taken- 
for-granted practices like the consultant-facilitated 'away day' can yield much of value in understanding the ways in which strategies are actually produced and are shaped by the conditions of production. Similarly, there is an emerging focus in new institutionalist approaches on what Lawrence and Suddaby (2006) term 'institutional work', that is, on how institutional outcomes, whether change or stasis, are achieved. This mirrors a similar focus in cultural sociology, where Wuthnow (1989: 538) has argued that 'culture is produced: it comes about through a series of actions, is expressed in action, and through action shapes the relations of individuals and societies'. This focus has lead to more attention being paid to the material expression of cultural phenomena like religion, encompassing ritual, performance and the built environment (Arweck and Keenan 2006). Wuthnow points out that an examination of the Reformation shows that it was not primarily the work of merchant capitalists but rather that it owed much of its success to the sponsorship of state administrators. Having won such a space it in turn contributed to broader developments by developing its own ideas.

Although it depended heavily on advances in literacy, demands for preaching in the vernacular, and the revival of biblical scholarship, insofar as Scripture was its most tangible symbol, it was also the reformers' most creative contribution. In pitting the godly, spiritual, and scriptural against the temporal world of institutional practice , they opened up an ideological space, as it were, in which to pose alternative forms of conduct and thought (Wuthnow 1989: 149).

So new forms of practice are developed which flow from religious commitments but have profound implications for other domains of activity. Becker and Wößmann (2007) thus 
suggest that the key impact of the Protestant Reformation was not ethical but the literacy produced as a consequence of the emphasis on the centrality of Scripture. They note that

The linguistic and methodical skills created by the teaching of God's Word reading, understanding, and knowing the Word, including its exegetical comprehension - are disposable in relation to other tasks that go beyond the religious realm ...But these alternative uses of the acquired education are purely unintentional and of no value to Luther and his Reformist circles (Becker and Wößmann 2007).

Others have also pointed to the way in which practices developed to further religious ends have broader impacts. Jeremy (1988b) explores some of these potential impacts in the case of William Mackintosh for the later nineteenth century, although his conclusions here are fairly tentative. He does suggest however, that 'a democratically-organized chapel possessed certain institutional features which could equip an individual for the world of business, as much as they could fit him for trade union leadership (a well-studied theme)' (Jeremy, 1988a: 13; cf Moore 1974). Accordingly, we move to a closer examination of such institutional features following a summary of the argument so far.

\section{Presbyterian forms of church governance and a 'culture of organization' in eighteenth century Scotland}

Forms of church organization are primarily developed to articulate the theological beliefs of denominations, shaped by transcendental experience. They may also be related to other 
elements of their broader social and cultural context, which may provide certain to-hand models, but belief is of prime importance. Such beliefs give rise to considerable differences in the forms of religious practice, both liturgical and governmental. Such practices become, over time, taken-for-granted and as such form resources on which church members can draw for their activities in other spheres. Religious belief in this way is mediated by religious practice. In this way, such practices may become primary for members of the denomination and in some senses be more concrete than belief. The grasp of specific examples of theological belief may be tenuous, but the taken-for-granted experience of religious practice on a regular basis can shape what come to be taken-for-granted ideas about legitimate forms of organization. That is, church membership may be empirically a matter of tradition or custom rather than belief. Zahniser warns us of the 'dangers in attributing this or that particular action on the part of any individual to religious belief' (Zahniser, 2005: 203). However, making the relation to religious practice relaxes this requirement. Our arguments rest not on whether belief is shared, but whether shared practices of church governance, related to belief and liturgical practice, shape a 'culture of organization'. In order to do this we need to explore what the nature of church governance practices might be and then home in more closely on the practices involved with one particular denomination, Scottish Presbyterianism.

Jeremy's (1988a) schematic anatomy of Christian churches in Britain provides one starting point for an examination of different practices. Jeremy classifies churches under a number of headings: theology; liturgy; local leaders; organisation/polity. This is a useful starting point, but needs far more detail for our purposes. Jeremy's account of organization is very much based on the form that a national church adopts, but this tends to cover up a number of key distinctions. One task, therefore, is to expand on these categories with a particular 
focus on the nature of lay involvement and church discipline. The category of theology in practice is rather unhelpful, as the vast majority of cases fit into a Trinitarian classification. Of more significance is the inclusion of a category for liturgy. In practice, this turns out to rest on a characterization of the form of worship, but here it will be argued that a focus on the sacrament of Communion has some interesting consequences for organizational arrangements, raising as it does questions about church membership. Finally, the nature of local leadership is important to consider in the context of lay involvement, as our discussion of Presbyterianism will indicate.

We can make a start on the organizational dimension of churches if we draw three broad distinctions between forms of national church polity (Demerath and Farnsley 2007). At one extreme are those churches clearly organised on a centralized national scale, with clearly defined hierarchies. The Roman Catholic church is the clearest example of this, but the Church of England and the varieties of Episcopalian denominations that share liturgical and organizational features are also significant. This can extend to some versions of Methodism, especially those which remained closest to their Anglican roots. The key figure here is the bishop, the lynchpin of a carefully graded hierarchy of offices in which the discipline flows essentially from top to bottom. The role for lay involvement here is limited. In the Church of England, for example, we have church wardens who have some responsibility to the congregation, but whose term of office is limited and whose powers are limited to maintenance of church fabric. At the other end of the spectrum are those churches which Jeremy notes as having local autonomy - Baptists, Congregationalists, some parts of Methodism and some smaller denominations. Some of these denominations, such as Methodists, had forms of local and national organization which involved both lay and clerical steering of activities of the local churches. In others, such as the Congregationalists, 
primacy was given to Congregational control. Even here, however, local forms of organization could differ in the extent of congregational control and involvement, from control through annual meetings to extensive delegation to a board of trustees or their equivalent. Between these two extremes, of centralized control through specific offices and local autonomy through congregational control, lay the Presbyterian form, most fully realised in Scotland, but stemming from Calvin and Geneva. Here there was a combination of a degree of local control in a system of central authority. That authority derived, however, not from specific officers but from the decisions arrived at through an annual General Assembly. This was constituted of both lay and clerical representatives derived from a system of structures, all of which had their role in discipline. At the base lay the Kirk Session, formally elected by the congregation and responsible to them, but holding office for life. This body had powers of discipline over both the congregation and the minister and in turn was subject to the discipline of the presbytery. This was a grouping of parishes with representation from both ministers and lay elders. In turn this contributed members to synods and thence onwards to the General Assembly. 'At every level,' suggests Kirk (1989: xix), 'individual action and initiative was made accountable to a concentric series of courts from kirk session to general assembly.' Key features of this polity, therefore, were discipline and systemic organisation.

This particular organizational arrangement arose, argues Kirk (1989), from the specific historical conjunction in Scotland in which, rather than being sponsored by the state, Reformation was carried out against a weak Crown by a popular movement allied to a faction of the nobility. This meant the new church was 'accorded that rare and exhilarating experience, denied to most churches, of determining its own programme and constitution' (Kirk 1989: xv). Strongly influenced by precedents in Geneva and other strongholds of the 
reformed church, and developed over a number of years, this form of organization placed a particular emphasis on discipline (Shaw 1964). Weber, as we have seen, rather neglects religious governance as a source of discipline, but it was central to the Scottish reformed church. In 1560-1, to complement their Confession of Faith, the newly formed General Assembly approved the First Book of Discipline (Cameron 1972). Strongly associated with the work of John Knox (Knox 1905), but prepared by a committee of the Assembly, this book laid out the organizational policy of the church. It was revised and rendered in more systematic fashion by the Second Book of Discipline in 1578 (Kirk 1980). This work, closely associated with Andrew Melville (McCrie 1856), saw the formalisation of the presbytery. This essential pattern of national church governance was subject to much contention, particularly with the efforts of successive monarchs to insert bishops into it. However, such efforts were sternly resisted and by the union of England and Scotland in 1707 the distinctive presbyterian pattern of church governance received specific safeguards (Stephen 2007). By the $18^{\text {th }}$ century, that is, a firmly established pattern of church governance had been established. This was not without dissension, particularly over the exercise of patronage at the local level and theological disagreements at national level, but it essentially provided for a cadre of organizers in every parish across the country who shaped taken-for-granted forms of accountability and record keeping. We can see this in action if we examine the responsibilities of the kirk session in respect of both the key sacrament of Communion and accounting for money.

In stark contrast to practice in the pre-reformed church, Communion was to be strictly limited both in the times when it was offered and those whom it was offered to (Holmes A 2006). 'Foure times in the yeare we think sufficient to the administration of the Lord's Table' argued the First Book of Discipline (Cameron 1972: 183), although the selection of 
frequency and dates was to be at the command of individual congregations. As practice evolved Communion was often held once a year, as preparation for participation was stressed. The Presbyterian church in Scotland held itself out as a national church rather than as a sect. We have seen how Weber (Gerth and Mills 1948: 312-3) emphasized the centrality of qualification for Communion in sects; in a church with pretensions to encompass the whole nation this increased the need for forms of discipline. From the time of the First Book of Discipline a key role was reserved for the Elders in their support of the minister:

For such as be so dull and so ignorant that they can neither try themselves nor know the dignitie and mysterie of that action cannot eate and drink of that Table worthily. And therefore of necessity we judge that everie yeare at the least, publick examination be had by the Ministers and Elders of the knowledge of every person within the kirk (Cameron 1972: 186).

This requirement was a difficult one to meet, either in rural areas with dispersed population or as urban parishes grew in population. Over time, therefore, organizational practices grew up to maintain records of membership. At Rayne in Aberdeenshire in 1772, for example, the Session minutes note that the last Sunday in June was 'intended as the day' for Communion. The minister pointed out that because of his health and the adverse state of the weather he 'had been kept from examining the parish in his Ordinary way. There would therefore be a Diet of catechizing in the Church for sometime and that they would begin this Afternoon (For references to Rayne see primary material, 22 May 1772). This was followed up closer to the event with the announcement that the Thursday before the Communion Sabbath was to be a 'day of Fasting, Humiliation and Prayer.' The minutes 
further record that it was 'Appointed the people of the Western side of the Parish to attend Thursday after the sermon to receive their Tokens' (21 June 1772). This latter mention introduces a very concrete symbol of the importance of membership in Presbyterian practice, the communion token. The session at Rayne possessed 'A Box filled with Tokens, with a stamp for striking tokens' (3 February 1772). Such tokens were given to those eligible for Communion, which had to be presented to elders stationed at the entrance to the venue in order to be allowed to proceed to the sacrament. Such tokens were later replaced by cards, but they required in their turn organizational practices. This came to be a register of communicants, which enabled the numbers of those eligible and attending to be determined year by year.

In this way we can relate theological beliefs about the nature of Communion and the eligibility of believers to partake in it to organizational practices. Such organizational practices fostered practices of detailed record keeping that were not necessary in other churches with looser criteria for membership. Another area was that of financial record keeping. It was a particular concern of the Reformed church that financial arrangements for the benefit of religion should not be siphoned off for secular purposes. Accordingly. much stress was placed on the role of the Deacons, who were to collect moneys owing to the church and arrange for their distribution, for the support of the minister, the relief of the poor and the upkeep of church buildings, as the session directed:

The Deacons shall be compelled and bound to make accounts to the Minister and Elders of that which they have received, as oft as the policie shall appoint; and the Elders when they are changed, which must be every yeare, must clear their accounts before such auditors as the Kirk shall appoint, and both the Deacons and 
Elders being changed, shall deliver to them that shall be new elected, all sums of money, cornes, and other profits remaining in their hands (Cameron 1972: 164).

While the treasurer was envisaged as only having an annual term of office and 'be not compelled to receive the office again for the space of 3 yeares' the oversight of the session who held office for life would give a strong degree of stability (Cameron 1972: 174). While in practice the desirable organizational arrangements might not be met, with treasurers holding office for long periods and elders being relieved of their duties, this system enabled a form of government that simply was not possible under other systems, such as the annual election of churchwardens in the Church of England. This meant that procedures could be put in place which assumed such stability. There is evidence, for example, of annual budgets being drawn up which presuppose the possibility of projecting costs and revenues in a way divorced from the personal circumstances of officials (Henderson 1935). Such divorce could mean that control shifted from personal trust to systemic measures. Thus in Rayne the 'Session being met and constitute Did immediately enter upon the Examination of their Treasurers Accounts and having carefully collected his Accounts with those held by their Clerk Found them agree in omnibus' (30 December 1772). This local focus was supplemented by the place of the Kirk Session in a national system of discipline in which forms of recording appear to have been handed down from a central point. The 'Register Book of Doctrine \& Discipline at Rayne' appears to have been kept in conformance with a common standard, which contrasts sharply with the wildly varying standards of record keeping in Anglican parishes (Mutch 2005).

The common standard was upheld by a strictly enforced pattern of accountability to the local presbytery. Not only were all ministers required to attend this, together with an elder 
from the session, but also regular visitations were carried out which were specified in considerable detail. That which was approved as policy in Aberdeenshire in 1675, for example, extends over eight printed pages (Bell 1897: 231-239). In such visitations ministers were questioned about their own practice, about the morals of the congregation and the conduct of the kirk session. In turn, the elders were questioned about their minister. Part of such visits consisted of examining the records that had been kept. In Kirkcaldy, Fife, in 1640, for example, it was reported to the Presbytery that the session book was examined and approved 'bot found fault that thair wer not yearlie or quarterlie compts of the poore folks silver resaveing and distributing etc.' (Stevenson 1900: 165). This emphasis on the recording of actions meant that considerable attention was paid to the nature of documentation. In 1650 the session records of Inverurie in Aberdeenshire record the 'Platform for Ordering Session Books' (Davidson 1878). Consisting of 27 articles, this lays out in considerable detail how records are to be kept, starting with the injunction 'That there be ane weell bound book of good paper, paged throughout, keeping a fair equable margent for the compend of acts' (Davidson 1878: 313). The language might be archaic, but the content is the analogue of a contemporary organizational procedure manual, down to the provision for the indexing ('compend') of decisions taken ('acts').

Through a long process of struggle and development, therefore, the presbyterian Church of Scotland had by the eighteenth century crafted a detailed tradition of church governance practices which created cadres of local organizers in every parish. While part of a national system of accountability, much emphasis was placed on lay involvement in the running of churches at the local level. While it is important not to over-estimate the degree of participation - kirk sessions were often self-perpetuating oligarchies and congregations often in practice had little say over the call and selection of their minister - this did create at 
the very least a tradition of lay involvement and a practical school for the transmission of practices of organizing. Flowing from theological and liturgical commitments, such practices had at their heart the detailed recording of decisions, accounts and membership. The recording of membership, vital for the effective policing of the annual Communion service, resulted in the creation of material culture, the communion tokens which signified preparedness for admission to the Communion table. The stability of the kirk session made it feasible to develop practices of accountability, such as budgeting (Henderson 1935). This engendered what Hall (1984) has called for the USA a ‘culture of organization'. Hall notes that

This subculture of individuals, trained to autonomy and accommodated to modes of corporate and proto-bureaucratic activity, would prove of immense importance not only in organizing the Civil War mobilization but also in creating and staffing the large-scale organizations that emerged after the war (Hall, 1992: 33).

He places the genesis of such individuals in the evangelical revival which swept the north eastern states in the 1820 s. Such a revival covered a range of faiths, not just Presbyterianism, but Presbyterians seemed to bring particular skills of organizing and, especially, record keeping to the cause (Ryan, 1981: 51). As Foster (1960) notes, Presbyterianism was particularly well suited to frontier settlements, bringing with it a ready made system of administration and justice. This strength of organization was manifested at a much earlier stage, with Tiedemann (2005) pointing to the importance of such forms of organization in the revolt against English rule in the middle colonies. Here, an instructive comparison is drawn between presbyterian and Anglican forms of 
organization. Once again, taken-for-granted practices of organizing become important mediating factors. We could extend this, as Hall does, to a comparison of other religious groupings. He notes, for example, there was a lack of traditions of trusteeship amongst Catholic immigrants to the USA 'in part because the issue of moral oversight, so central to the stewardship dimension of traditional trusteeship, tended to be left to ecclesiastical authorities in Catholic communities' (Hall, 1992: 143). It is not, as he points out, that there was no voluntaristic activity amongst such groups but rather that this took different organizational form. One is reminded of the form of lay participation in pre-Reformation England chronicled by Duffy (2001) for Morebath in Devon. Here different lay groups took responsibility for the upkeep of chapels or statues. Funds were raised by the rearing of sheep which ran with the members' flocks and were sold at appointed occasions. This is a very different form of participation which, it could be argued, did not provide the same opportunities for training in organizational matters that governance practices like those of presbyterianism afforded.

However, it is important that we are not claiming that presbyterianism in and of itself was the sole cause of a particular culture of organization which had wider ramifications. Rather, it was part of a nexus of inter-related institutions which deserve brief consideration. Of particular importance here were the law, education and the economy. We have noted already that a feature of the Union settlement between England and Scotland in 1707 was the preservation of the presbyterian Church of Scotland. Also protected was the Scottish legal system, which had different intellectual roots from that which had developed in England. Scottish law borrowed much more heavily from Roman Law, a feature of which was an emphasis on 
systematisation (Walker 1998). This emphasis on codification sat well with what Harvie has described as a church espousing an approach 'both legalistic in its Talmudic attitude to scriptures and deeply preoccupied with church government and social discipline' (Harvie, 1999: 63). The training of lawyers in such a system was both broader and more academic than that in England from the period of the Enlightenment. In addition, the ties between church and law were embodied ones. Many distant and poorer presbyteries nominated Edinburgh lawyers to be their representatives at the General Assembly, leading McIntosh (1998) to argue that this produced disproportionate numbers of lawyers in the national deliberations of the church. Such lawyers operated in a system that was heavily dependent on the production of written arguments, in their turn dependent on a set of decisions 'put in rational order and systematised by a number of scholarly writers whose works were accepted of high value and considerable persuasive authority' (Walker 1998: 819). Some of the emphasis on written accountability and the systematic statement of policy that we have observed in the church, that is, may have been reinforced, and indeed influenced, by legal practices.

At the heart of Knox's blueprint for a reformed society as laid out in the Book of Discipline was a whole system of education with paths from schools in every parish to universities to train, principally, the next generation of ministers and school masters. Once again there is the focus on systems of inter-connected parts drawing in the whole country. Whilst educational provision might in practice have been patchy, it produced a very much more literate population than in most of the rest of the Europe (Anderson, 1985). This education also developed a distinctly vocational flavour, with an emphasis on basic book keeping which meant that Scotland supplied many of the 
book keepers for the slaving economy of the Caribbean (Hamilton 2005). In a more positive light, the growth of literacy also stimulated a vigorous publishing industry One fruit of this literate culture was the remarkable series of accounts of each parish published in the late eighteenth century and known as the Statistical Accounts. Generally written by the minister of each parish these vary enormously in quality and coverage, but the enterprise itself reflects an attitude towards social investigation, soon to be mirrored in further reports on the agriculture of each county, which was considerably in advance of its time. This was supplemented by the first modern census of population, organised in 1755 by the Edinburgh minister Alexander Webster (Buchan, 2003). Holmes (2006) notes that many of the accounts of agriculture were written by local tenant farmers. One such was Andrew Blaikie of Bowden in the Borders. His son, Francis was to go on to be one of the most influential land agents in Britain, at the forefront of the changes in agricultural practice which saw dramatic rises in productivity. He was in turn deeply involved in matters of church governance (Parker 1975). Again we see the close relationship between patterns of church governance and the training in literacy and organizing which could valuably be translated to other fields of activity.

This translation can be seen if we consider the development of the Scottish economy. Scotland in the early eighteenth century was a poor and under-developed country, but one which was to develop a highly advanced agricultural sector (Davidson 2000; 2003). Under the banner of 'improvement' this was, by necessity, a landlord-led programme. Landlords invested considerable sums in developing model home farms, reorganizing leases and planting trees. Unlike much practice in England at the time, much of this development rested on the granting of nineteen year leases, leases which 
often specified in considerable detail the course of cultivation to be followed. The administration of such estates rested heavily on legally trained 'factors' or estate managers (Devine 2006). This in turn prompted the production of account books, such as that produced by David Young, a Perth merchant and former tenant farmer, in 1790 (Holmes 2006). The high levels of literacy amongst tenant farmers and the existence of institutions such as circulation libraries meant that these were ideal mechanisms for the further transmission of agricultural knowledge in such a way that areas such as East Lothian became demonstration areas of excellence for the whole of Britain. A further consequence of such developments might have been the broad acceptance of managers as an appropriate way of running commercial and industrial establishments, accompanied by legal developments in the status of public trading bodies. Thus Walker notes that

The typical pattern was for merchants to act as sleeping partners in an industrial firm, in many cases contributing the bulk of the stock, but relying on skilled personnel to superintend the daily routine of production and management (Walker 1998: 687).

This was facilitated by a different attitude to the status of partnerships in Scottish law. Campbell (1967) points out that the case of McNair v. Stevenson of 1757 established that partners to a joint stock trading company were only liable to the extent of their subscription. It is interesting to note in the light of our earlier discussion about the relationship of church and law that Campbell goes further to note that in 1791 a judgement recognized the kirk session of Dalry as a body corporate (Duncan 1869). This perhaps suggests an overlap between conceptions of religious governance and of 
commercial organization, although Campbell does not develop this point. It is one which could stand further investigation.

Devine notes the significance of the different status accorded to partnerships under Scots law and its influence of the development of trading activities in Glasgow. He suggests that the industrialisation fostered by Glasgow tobacco merchants was closely tied to both the wealth generated by their trading with the Americas and the need for goods to reinforce their trading position. This had consequences for the way in which they were run: 'The enterprises were of the 'factory' type, highly capitalized and often employing many dozens of people' (Devine 2003: 332). This meant that when industries such as cotton spinning developed, investors were willing to develop the techniques supplied by English entrepreneurs such as Arkwright and entrust the running of their mills to salaried managers. The pairing of David Dale and Robert Owens at New Lanark is simply the most famous example of such an arrangement. It was this environment that was to produce what has been termed the 'first management text', James Montgomery's The Carding and Spinning Master's Assistant, or, The Theory and Practice of Cotton Spinning in 1832 (Gantman 2005; Chandler 1979).

\section{Conclusion: church governance and to-hand models of organizing.}

The example of James Montgomery is only one of a cluster of management innovations associated with Scottish and 'Scotch Irish' Presbyterians in the later years of the eighteenth century and the nineteenth century, the dynamic years of industrial 
and commercial developments in which so many organizational arrangements first appeared. The first Chamber of Commerce was formed in Glasgow in 1783, to be followed by the first professional association of accountants in Edinburgh in 1853 (Walker 1998; Walker 1995). Scotland was the source of accounting textbooks in the eighteenth century which became the accepted orthodoxy in the following century, with much influence in the United States (Mepham 1994). We have already met Francis Blaike, leading land agent; his influence in estate management was to be consolidated by James Loch (Spring 1963; Richards 1973). Montgomery's work of systematisation in the cotton industry was to be followed by McCallum on the American railroads (originator, Chandler tells us, of the organization chart) (Chandler 1962; Beninger 1986). In brewing, Andrew Barclay Walker was the originator of the direct management of public houses and Andrew Wedderburn and other Scots had considerable influence in reporting arrangements within the Hudson Bay Company in Canada (Mutch 2006; Spraakman and Marget 2005). All of these examples are marked by a common focus on system, accountability and recording. These practices can be seen, it has been argued, to stem in large part from the organizational practices of the Presbyterian form of church governance. These influences have to be seen in the context of broader institutional arrangements. Their working out in practice depends on the detailed investigation of particular contexts, but enough has been said, it is hoped, to point to the fruitfulness of a focus on practices of religious governance.

A focus on taken-for-granted practices as forming to-hand resources for use in another field avoids the problems of functionalism that we noted earlier. Holmes, in his study of Ulster Presbyterianism, speaks for recent historians of religion in noting that, whilst 
there may be important political or economic outcomes of religious belief and practice,

Church historians in particular are reticent about the implications of any type of economic or social determinism upon the content, validity, and integrity of personal belief. It is important to examine any ideas, whether religious or otherwise, within the social and cultural context from which they emerge, without regarding them as being wholly determined by that context or blindly accepting an unsatisfactory relativism (Holmes A 2006: 15).

Of course, it could be argued that the search for order in both religious and economic activity can be related to a more general impulse towards rationalisation. Hennis (1988) cautions us against associating such views with Weber, who, he argued, was suspicious of any such universalizing claims. 'In Protestant Ethic', he argues 'Weber investigated one characteristic factor, a 'plastic element' of modern Lebensführung: ascetic Protestantism in its effects on the idea of vocation' rather than any universal tendency (Hennis 1988: 44). In more recent inquiries into the shaping of science in the early modern period, Shapin (1998) points to the articulation between political concerns with order and forms of scientific investigation. Closely linked to such articulation was, in the work of Jacob and Jacob (1980), the church governance practices of Anglicanism which privileged the bishop as the mediator of knowledge claims and so, it is suggested, shaped images of the scientist as expert as against the more democratic truth claims of radical sectaries. A focus on governance practices enables us to make abstract notions of order and rationalisation more concrete. 
It also enables us to specify more closely how questions of belief might articulate with practice in other fields. This is not to argue that belief is unimportant. As we have seen many practices stem from matters of belief rather than being a pale reflection of material conditions. But it is to shift the focus in the manner of Wuthnow to look at how beliefs, as with culture more generally, are brought into articulation with institutional contexts. As he notes

Culture is understood here not as some subjective or idealized world view that is to be distinguished from behavior but as a form of behavior itself and as the tangible results of that behavior....The important point is that culture, as conceived here, is explicitly produced rather than simply being implicitly embedded in, or constitutive of, social arrangements (Wuthnow 1989: 15).

One of the key outputs of such processes of production is practices, practices which come to be taken for granted as they are endlessly repeated. It is this taken for granted quality that then renders them available as commonsense templates for organizing in other domains. Such a practice-based approach offers an alternative to the focus on aggregates of individuals that emerges from, for example, the prospographical approach essayed by Jeremy (2002). Responding to the criticism that it is hard to find concrete links between faith and business practices at the individual level, he suggests that collective biography will yield more robust results. However, there is a danger here of substituting quantity for quality, with social trends being reduced to aggregates of individuals. Rather, a focus on practice points us to the importance of channels for dissemination, which might not rely on individuals but rather institutions. Thus, for example, the educational practices of Scottish Presbyterianism have been 
held to be a significant force in the training of entrepreneurs active in the English Industrial Revolution (Ashton 1968; McKendrick 1964). A focus on organizing practices derived from church governance may help us further consolidate this influence mechanism and aid our understanding of the early development of modern management.

Two limitations to this conclusion, however, should be noted. One is an empirical one. The evidence drawn upon in this discussion has been largely taken from secondary sources, although limited archival work seems to confirm the broad outlines of the governance practices sketched here. The kirk session records of Scotland have been mined as a rich source for social history (Todd 2002, Hanham 2005) but remain to be analyzed for what they tell us about governance practices in any systematic and structured fashion. The second limitation is that the discussion has been restricted to Christian denominations. We have noted that Weber's discussion of other faiths tends to be related to belief systems in relation to particular practices. For example, Economy and Society (Weber 1968) has extensive discussion of the relationship of major world religions to commercial practice. This tradition of a focus on beliefs rather than practice can be seen in more contemporary treatments (Ali 2005). The suggestion here of the value of turning an organizational lens on to religion in order to see how taken for granted patterns of lay involvement in church governance provide templates for organizing elsewhere might be extended to other religious traditions. In a globalising world, systematic and patterned differences in management style and practice become more salient (Ganter and Walgenbach 2002; Lehrer 2001). Analysts in the comparative business systems perspective attribute such differences to clusters of inter-related institutions, reinforced by cultural values 
(Whitley 2000). In the latter, religion plays an important, if somewhat neglected part. A focus on practices of church governance might help the deepening of such analyses.

\section{Acknowledgments}

My thanks to participants in two streams at the European Group for Organization Studies colloquia in Bergen and Amsterdam at which previous versions of this article were presented, and for suggestions made by participants in seminars at Oxford and Nottingham Trent University.

\section{References}

\section{Primary material}

National Archive of Scotland, $\mathrm{CH} 2 / 310 / 5$, parish of Rayne, Aberdeenshire, Minutes 1744-1772, accounts 1744-1770

\section{Secondary}

Albrow, M. (1994) 'Accounting for Organizational Feeling', In Reed, M. and Ray, L. (eds) Organizing Modernity: New Weberian Perspectives on Work, Organization and Society, London: Routledge 98-121. 
Ali, A. J. (2005) Islamic Perspectives on Management and Organization,

Cheltenham: Edward Elgar.

Anderson, R. (1985) 'In Search of the 'Lad of Parts': The Mythical History of Scottish

Education', History Workshop, 19, 82-104.

Archer, M. S. and Tritter, J. Q. (2000) Rational Choice Theory: Resisting

Colonization, London: Routledge.

Archer, M. (2004) 'Models of Man: The Admission of Transcendence', in Archer, M.,

. Collier, A. and Porpora, D. (eds.) Transcendence: Critical Realism and God,

London: Routledge 63-81.

Armitage, D. (2005) 'The Scottish Diaspora', in Wormald, J. (ed.) Scotland: A

History, Oxford: Oxford University Press 272-303.

Arrington, L. J. and Bitton, D. (1979) The Mormon Experience: A History of the

Latter-day Saints, London: Allen \& Unwin.

Arweck, E., and Keenan, W. (2006) Materializing Religion: Expression, Performance and Ritual, Aldershot: Ashgate.

Ashton, T. S. (1968) The Industrial Revolution, 1760-1830, Oxford: Oxford University Press.

Becker, S., and Wößmann, L. (2007) Was Weber Wrong? A Human Capital Theory of Protestant Economic History, discussion paper, Department of Economics, University of Munich, http://Epub.ub.uni-munchen.de.

Bell, T. (1897) Records of the Exercise of Alford 1662-1688, Aberdeen: New Spalding Club.

Beninger, J. R. (1986) The Control Revolution: Technological and Economic Origins of the Information Society, Cambridge, Mass.: Harvard University Press.

Boltanski, L. and Chiapello, E. (2007) The New Spirit of Capitalism, London: Verso. 
Buchan, J. (2003) Capital of the Mind: How Edinburgh Changed the World, London: John Murray.

Burke, P. (1988) 'Republics of Merchants in Early Modern Europe', in Baechler, J., Hall, J. and Mann, M. (eds.) Europe and the Rise of Capitalism, Oxford: Blackwell 220-233.

Cameron, J. (1972) The First Book of Discipline, Edinburgh: Saint Andrew Press. Campbell, R. H., (1967) 'The Law and the Joint-Stock Company in Scotland', in.

Payne, P. L. (ed) Studies in Scottish Business History, Frank Cass, London, 136-151

Campbell, C. (2006) 'Do Today's Sociologists Really Appreciate Weber's Essay The Protestant Ethic and the Spirit of Capitalism?', The Sociological Review, 54(4) 207223.

Chalcraft, D. (1994) 'Bringing the Text Back in: On Ways of Reading the Iron Cage Metaphor in the Two Editions of The Protestant Ethic', In Reed, M. and Ray, L. (eds) Organizing Modernity: New Weberian Perspectives on Work, Organization and Society, London: Routledge 16-45.

Chalcraft, D., and Harrington, A. (2001) The Protestant Ethic Debate: Max Weber's Replies to his Critics, 1907-1910, Liverpool: Liverpool University Press.

Chandler, A. D. (1962) 'Henry Varnum Poor, Philosopher of Management, 18121905', in Miller, W. (ed.) Men in Business, New York: Harper \& Row 254-285. Chandler, A. D. (1979) Precursors of Modern Management: A Reprint of Montgomery, Carding and Spinning Master's Assistant and Major James Dalliba, Armory at Springfield, New York: Arno Press.

Davidson, J. (1878) Inverurie and the Earldom of the Garioch: A Topographical and Historical Account of the Garioch from the Earliest Times to the Revolution Settlement, Edinburgh: David Douglas. 
Davidson, N. (2000) The Origins of Scottish Nationhood, London: Pluto.

Davidson, N. (2003) Discovering the Scottish Revolution 1692-1746, London: Pluto.

Demerath, N. J. and Farnsley A. E. (2007) 'Congregations resurgent' in Beckford J. and Demerath, N. J. (eds) The Sage Handbook of the Sociology of Religion, London: Sage, 193-204.

Devine, T. (2003) Scotland's Empire 1600-1815, London: Allen Lane.

Devine, T. (2006) Clearance and Improvement: Land, Power and People in Scotland 1700-1900, Edinburgh: John Donald.

DiMaggio, P. and Powell, W. (1991) 'The Iron Cage Revisted: Institutional Isomorphism and Collective Rationality in Organization Fields', in Powell W. and DiMaggio P. (eds.) The New Institutionalism in Organizational Analysis, Chicago: University of Chicago: 63-82.

DiMaggio, P. (1998) 'The Relevance of Organization Theory to the Study of Religion', in Demerath N. J., Hall, P. D., Schmitt, T. and Williams, R. (eds) Sacred Companies: Organizational Aspects of Religion and Religious Aspects of Organizations, New York: Oxford University Press, 7-23.

Duffy, E. (2001) The Voices of Morebath: Reformation and Rebellion in an English village, New Haven, Ct: Yale University Press.

Duncan, J. (1869) Treatise on the Parochial Ecclesiastical Law of Scotland, 2nd edition, Edinburgh: Bell and Bradfute.

Dyck, B., Starke, F., Harder, H. and Hecht T. (2005) 'Do the Organizational Structures of Religious Places of Worship Reflect Their Statements of Faith? An Exploratory Study', Review of Religious Research, 47(1) 51-69.

Ekelund, R., Hebert, R., and Tollison, R. (2006) The Marketplace of Christianity, Cambridge MA: MIT Press. 
Foster, C. (1960) An Errand of Mercy: The Evangelical United Front 1790-1837,

Chapel Hill, NC: University of North Carolina Press.

Ganter, H., and Walgenbach, P. (2002) 'Middle Managers: Differences Between

Britain and Germany', in M. Geppert, Matten, D. and Williams, K. (eds) Challenges for European Management in a Global Context, Basingstoke: Palgrave Macmillan $165-188$.

Gantman, E. (2005) Capitalism, Social Privilege and Managerial Ideologies, Aldershot: Ashgate.

Garnett, J. (1999) 'Nonconformists, Economic Ethics and the Consumer Society in Mid-Victorian Britain', in Shaw, J. and Kreider, A. (eds) Culture and the Nonconformist Tradition, Cardiff: University of Wales Press 95-116.

Gerth, H., and Mills, C. W. (1948) From Max Weber: Essays in Sociology, London: Routledge \& Kegan Paul.

Goldstein, W. (2006) Marx, Critical Theory and Religion: A Critique of Rational Choice, Leiden: Brill.

Hall, P. D. (1984) The Organization of American Culture, 1700-1900: Private Institutions, Elites and the Origins of American Nationality, New York: New York University Press.

Hall, P. D. (1992) Inventing the Nonprofit Sector and other Essays on Philanthropy, Voluntarism and Nonprofit Organizations, Baltimore, MD: John Hopkins University Press.

Hamilton, D. (2005) Scotland, the Caribbean and the Atlantic World 1750-1820, Manchester: Manchester University Press.

Hanham, A. (2005) Sinners of Cramond: The Struggle to Impose Godly Behaviour on a Scottish Community, 1651-1851, Edinburgh: John Donald. 
Harvie, C. (1999) Travelling Scot: Essays on the History, Politics and Future of the Scots, Glendaruel, Argyll: Argyll.

Henderson, G. D. (1935) The Scottish Ruling Elder, London: James Clarke \& Son. Hennis, W. (1988) Max Weber, Essays in Reconstruction, London: Allen \& Unwin. Holmes, A. (2006) The Shaping of Ulster Presbyterian Belief and Practice 17701840, Oxford: Oxford University Press.

Holmes, H. (2006) 'The Circulation of Scottish Agricultural Books During the Eighteenth Century', Agricultural History Review, 54(1) 45-78.

Jacob, J. R. and Jacob, M. C. (1980) 'The Anglican Origins of Modern Science: The Metaphysical Foundations of the Whig Constitution', Isis, 71(2), 251-267.

Jeremy, D. (1988) Business and Religion in Britain, Aldershot: Gower.

Jeremy, D. (1988) 'Chapel in a Business Career: The Case of John Mackintosh (18681920)', in Jeremy, D. (ed.) Business and religion in Britain, Aldershot: Gower 95117.

Jeremy, D. J. (2002) 'Business history and strategy', in Pettigrew, A., Thomas, H. and Whittington R. (eds.) Handbook of Strategy and Management, London: Sage 436460.

Kiernan, V. (1992) 'Scottish soldiers and the conquest of India', in Simpson, G. G. (ed), The Scottish Soldier Abroad 1247-1967, Edinburgh: John Donald 97-110.

Kirk, J. (1980) The Second Book of Discipline, Edinburgh: The Saint Andrew Press. Kirk, J. (1989) Patterns of Reform: Continuity and Change in the Reformation Kirk, Edinburgh: T \& T Clark.

Knox, J. (1905) The History of the Reformation of Religion in Scotland by John Knox; With which are Included Knox's Confession and The Book of Discipline, London: Melrose. 
Lawrence, T., and Suddaby, R. (2006) 'Institutions and Institutional Work', in Clegg,

S., Hardy, C., Lawrence, T. and Nord, W. (eds) Handbook of Organization Studies

(2nd Edition), London: Sage 215-254.

Lechner, F. J. (2007) 'Rational Choice and Religious Economies' in Beckford J. and

Demerath, N. J. (eds) The Sage Handbook of the Sociology of Religion, London: Sage, 81-97.

Lehrer, M. (2001) 'Macro-varieties of Capitalism and Micro-varieties of Strategic Management in European Airlines', in Hall, P. and Soskice, D. (eds), Varieties of Capitalism, Oxford: Oxford University Press 361-386.

Marshall, G. (1980) Presbyteries and Profits: Calvinism and the Development of Capitalism in Scotland, 1560-1707, Oxford: Clarendon Press.

McCrie, T. (1856) Life of Andrew Melville, Edinburgh: William Blackwood McIntosh, J. (1998) Church and Theology in Enlightenment Scotland: The Popular Party 1740-1800, East Linton: Tuckwell.

McKendrick, N. (1964) 'Josiah Wedgwood and Thomas Bentley: an InventorEntrepreneur Partnership in the Industrial Revolution', Transactions of the Royal Historical Society, 5th series, 14, 1-33.

Mepham, M. J. (1994) 'The Scottish Enlightenment and the Development of Accounting', in Parker, R. and Yarney B. (eds.) Accounting History: Some British Contributions, Oxford: Oxford University Press, 268-296.

Moore, R. (1974) Pitmen, Preachers and Politics: The Effects of Methodism in a Durham Mining Community, London: Cambridge University Press.

Mutch, A. (2005). 'Management Practice and Kirk Sessions: An Exploration of the Scottish Contribution to Management', Journal of Scottish Historical Studies, 24(1): $1-19$. 
Mutch, A. (2006) 'Public Houses as Multiple Retailing: Peter Walker \& Son 18461914’, Business History, 48(1), 1-19.

Parker, R. (1975) Coke of Norfolk: A Financial and Agricultural Study 1707-1842, Oxford: Clarendon.

Prior, A. and Kirby, M. (1993) 'The Society of Friends and the Family Firm, 17001830', Business History, 35(4) 66-85.

Richards, E. (1973) The Leviathan of Wealth: The Sutherland fortune in the Industrial Revolution, London: Routledge \& Kegan Paul.

Ryan, M. P. (1981) Cradle of the Middle Class: The Family in Oneida County, New York: Cambridge University Press.

Scott, W. R. (2001) Institutions and Organizations, London: Sage.

Shapin, S. (1998) The Scientific Revolution, Chicago: University of Chicago.

Shaw, D. (1964) The General Assemblies of the Church of Scotland 1560-1600: Their Origins And Development, Edinburgh: Saint Andrew Press.

Spraakman, G., and Marget, J. (2005) 'The Transfer of Management Accounting Practices from London Counting Houses to the British North American Fur Trade', Accounting, Business and Financial History, 15(2), 101-119.

Spring, D. (1963) The English Landed Estate in the Nineteenth Century: Its Administration, Baltimore: John Hopkins Press.

Stephen, J. (2007) Scottish Presbyterians and the Act of Union, 1707, Edinburgh: Edinburgh University Press.

Stevenson, W. (1900) The Presbytrie Booke of Kirkcaldie (1630-1653), Kirkcaldy: James Burt.

Stout, H. S. and Cormode, D. S. (1998) 'Institutions and the Story of American Religion: a Sketch of a Synthesis', in Demerath N. J., Hall, P. D., Schmitt, T. and 
Williams, R. (eds) Sacred Companies: Organizational Aspects of Religion and Religious Aspects of Organizations, New York: Oxford University Press, 62-78.

Tiedemann, J. (2005) 'Presbyterianism and the American Revolution in the Middle Colonies', Church History, 74(2) 306-344.

Todd, M. (2002) The Culture of Protestantism in Early Modern Scotland, New Haven: Yale University Press.

Walker, S. P. (1995) 'The Genesis of Professional Organization in Scotland: A Contextual Analysis', Accounting, Organizations and Society, 20(4) 285-310.

Walker, D. (1998) A Legal History of Scotland, Vol V The Eighteenth century, Edinburgh: T \& T Clark.

Wall, J. F. (1970) Andrew Carnegie, New York: Oxford University Press.

Weber, M. (1968a) Economy and Society, vol 1, Berkeley: University of California Press.

Weber, M. (1968b) Economy and Society, vol 2, Berkeley: University of California Press.

Weber, M. (1976) The Protestant Ethic and the Spirit of Capitalism, London: Allen and Unwin.

Whitley, R. (2000) Divergent Capitalisms: The Social Structuring and Change of Business Systems, Oxford: Oxford University Press.

Whittington, R. (2006) 'Completing the Practice Turn in Strategy Research', Organization Studies, 27(5) 613-634.

Wuthnow, R. (1989) Communities of Discourse: Ideology and Social Structure in the Reformation, the Enlightenment, and European Socialism, Cambridge, MA: Harvard University Press. 
Zahniser, K. (2005) Steel City Gospel: Protestant Laity and Reform in Progressiveera Pittsburgh, New York: Routledge.

\footnotetext{
${ }^{1}$ The Aston programme in organization theory, active in the 1970s, sought to relate aspects of organizational structure to key environmental variables and, in turn, to organizational performance.
} 